\title{
Article \\ Prevalence and Characteristic of Oral Mucosa Lesions
}

\author{
Małgorzata Radwan-Oczko ${ }^{1}$, Iga Sokół ${ }^{2}$, Katarzyna Babuśka ${ }^{2}$ and Joanna E. Owczarek-Drabińska ${ }^{1, *(D)}$ \\ 1 Department of Oral Pathology, Wroclaw Medical University, 50-367 Wrocław, Poland; \\ malgorzata.radwan-oczko@umw.edu.pl \\ 2 Student Scientific Society of Oral Health, Department of Oral Pathology, Wroclaw Medical University, \\ 50-367 Wrocław, Poland; iga.sokol@student.umw.edu.pl (I.S.); Katarzyna.babuska@student.umw.edu.pl (K.B.) \\ * Correspondence: joanna.owczarek@umw.edu.pl; Tel.: +48-71-784-03-81
}

Citation: Radwan-Oczko, M.; Sokół, I.; Babuśka, K.; Owczarek-Drabińska, J.E. Prevalence and Characteristic of Oral Mucosa Lesions. Symmetry 2022, 14, 307. https://doi.org/10.3390/ sym14020307

Academic Editors:

Anna Paradowska-Stolarz,

Irena Duś-llnicka and Maria

Cristina Pollmann

Received: 22 December 2021

Accepted: 30 January 2022

Published: 2 February 2022

Publisher's Note: MDPI stays neutral with regard to jurisdictional claims in published maps and institutional affiliations.

Copyright: (c) 2022 by the authors. Licensee MDPI, Basel, Switzerland. This article is an open access article distributed under the terms and conditions of the Creative Commons Attribution (CC BY) license (https:// creativecommons.org/licenses/by/ $4.0 /)$.

\begin{abstract}
Background: Oral mucosa lesions (OMLs) are diagnosed worldwide in any population, age or gender, but in varied prevalence. OMLs can be found in each site of the oral mucosa; for some of them, it is characteristic to have a bilateral/symmetrical or unilateral/nonsymmetrical mucosal manifestation. The knowledge about its prevalence in varied populations can be useful from a clinical point of view. The aim of this study is to assess the prevalence of OMLs in patients attending outpatient dental clinic; (2) Retrospective analysis of 2747 patients' oral cavity medical charts, who referred to oral pathology outpatient clinic. The type of diagnosed oral lesion, sex and age were evaluated. $p \leq 0.05$ was considered statistically significant; (3) Results: In this study, the overall prevalence of oral mucosal lesions was found to be higher in older than younger patients. In our study, the age median was the highest in patients with xerostomia, burning mouth syndrome, angular cheilitis and oral candidiasis. The youngest median age was observed in patients with aphthae, mucocele and gingival enlargement. The higher OMLs frequency was related with the female gender. (4) It is important for clinicians to be familiar not only with distinctive features, which sometimes may not be clear, but also with linking the occurrence of OMLs with the gender and age.
\end{abstract}

Keywords: oral health; oral mucosa lesions; prevalence; oral lichen planus; aphthae; leukoplakia

\section{Introduction}

Oral mucosa lesions (OMLs) are the third-most common oral pathology after caries and periodontal diseases.

Those lesions are diagnosed worldwide in any population and in any age but in varied prevalence. Oral lesions may impede the oral health-dependent quality of life, in particular causing severe pain of chronic and acute lesions. Those painful conditions may restrict food intake, hinder oral hygiene and interfere with swallowing or speaking. It must not be forgotten that many OMLs are benign and self-limiting, and patients may not even realize their presence in oral cavity. Lesions are diagnosed in different sites of oral cavity. Most of them can be found nonsymmetrically. In some cases, the lesion may cover the entire surface of the oral mucosa. Another can manifest bilaterally, e.g., on the buccal or lingual mucosa [1-6].

Due to the fact that the clinical appearance of oral mucosa lesions can be very similar and resemble one another, dental clinicians must be aware of a wide range of their different etiology and background.

In etiopathology of oral mucosa conditions, many different, both local and general, factors are known, which can be eliminated during the proper treatment [7-10].

Among the many causes of oral mucosa pathologies, the development of irritating local factors, related with trauma to the oral cavity, is of great importance. The presence of sharp teeth edges or dentures elements that may hurt oral mucosa, even during physiological activity such as: biting, chewing or speaking, also behavioral factors such as smoking, improper hygiene level with the calculus and plaque presence, oral parafunctions and 
intraoral piercing, which are responsible for oral mucosa injuries, can be the most frequent triggering factors. Those injuries may also result from iatrogenic-mechanical, chemical or thermal trauma during dental treatment [11].

Other seminal irritating local factors are connected to denture use and the low level of saliva flow with the presence of xerostomia [12-14]. The long term and rife use of the antibacterial mouthwashes and dentifrices, whitening toothpastes, herbal solutions with the anti-inflammatory and antiseptic potential are also considered to have the influence on the appearance of abnormalities and changes in oral mucosa epithelium [15]. In such cases, where only oral local factors are taken into consideration, accurate oral investigation and in-depth anamnesis enable one to make proper diagnosis and implement the right treatment.

A lot of different oral lesions, both pathological and congenital, have their origins in systemic conditions. Those that are mostly seen and discussed are related to: oral mucosa anomalies, genetic predispositions, skin diseases, blood dyscrasias, autoimmunological and immunological disorders, gastrointestinal diseases, virus infections, fungal infections, side effects of the general chemotherapy and radiotherapy treatment, oral side effects and hypersensitivity to systemic drugs, and various nutritional deficiencies, such as: vitamin $B$ deficiency, iron deficiency, and microelements malabsorption.

Because of these diversified etiopathology and origins, various oral mucosa lesions are typically more often diagnosed in young, middle-age and older people. This knowledge about the prevalence of mucosal lesion in varied populations is useful from the practi$\mathrm{cal} /$ clinical point of view. This helps in the introduction of an early prophylaxis against some of the diseases and its complications [1,3,10,16-25].

Many lesions have known etiopathology and can be treated and eliminated easily and effectively. However, some of the lesions have an unknown and unclear origin and can be treated only symptomatically. In some cases, because of many general and local signs and symptoms, OMLs require interdisciplinary approach with the cooperation of different medical specialists in order to restore patients general and oral health.

The aim of the study was to assess and describe the prevalence of clinically diagnosed oral mucosa lesions in patients attending outpatient dental clinic for diagnosis and treatment.

\section{Materials and Methods}

Retrospective analysis of patients oral cavity medical charts, who referred to oral pathology outpatient clinic between 2015 and 2019, was carried out. Patients came from southwestern part of Poland. Medical files with the record of oral mucosa lesion diagnoses were included into further investigation. The files investigation was performed by the specialist in oral pathology with the help of previously trained and calibrated dentistry students.

Diagnoses of the mucosal lesions, found in the medical charts, were made mainly on the basis of oral cavity examination, observation and clinical interview. Diagnostic recognition of lesions and pathologies such as traumatic lesions, BMS, aphthae, geographic and hairy tongue, morsicattio buccarum, glossodynia, gingival enlargement, hemangioma, xerostomia, frictional hyperkeratosis, angular cheilitis and desquamative gingivitis were based on its clinical appearance and patients' meticulous anamnesis. In the case of clinical necessity or doubts as to the preliminary diagnosis to certain oral mucosa diseases, additional diagnostic methods were implemented. Therefore, in order to confirm the clinical diagnoses of oral lichen planus and oral lichenoid lesions, mucocele, epulis and papilloma, a biopsy with full histopathology was performed. Moreover, in the case of suspicion of oral candidiasis and denture stomatitis, a mycological examination was always performed to confirm the initial diagnosis and start the treatment. Desquamative gingivitis (DG) is a term used for a specific clinical symptoms: vesicular formation, atrophy, erosion and desquamation, characterized with diffuse erythema of the marginal and keratinized gingiva. It can be a clinical manifestation of several disease, such as: oral lichen planus, 
mucous membrane pemphigoid and pemphigus vulgaris or contact allergic reactions. The clinical diagnosis of DG was always followed by the further investigation to determine the underlying disease [26]. We diagnosed glossodynia when pain, burning sensation and other subjective symptoms were confined to the tongue only. By contrast, BMS was diagnosed when the same complaints were spread to different areas of the mouth (gingiva, hard palate, etc.), also with the tongue involvement. To simplify the results and interpretation of our study some diagnosed lesions, such as: white and white-atrophic OLP/OLL, erosive and bullous OLP/OLL, erosions and ulcers were grouped together. Candidiasis and denture stomatitis due to the different patients profile and its clinical appearance were presented and discussed separately.

In total, 2747 medical charts were included into the study. The elements evaluated from the health records were: type of diagnosed oral lesion, sex and age of the patient. No other personal data were collected or described. The informed consent was obtained from each patient or her/his legal guardians during the phone conversation. The approval of the local ethics committee was not required, due to retrospective data used and no possibility to identify an individual person from the data that were collected from the medical files.

The results were statistically analyzed. Continuous data were presented as median (M), lower and upper quartile (25-75Q), and range (min-max). The verification of the hypothesis about the equality of the mean parameters in independent groups was carried out by the ANOVA method of variance analysis or for groups with heterogeneous variance with the nonparametric Mann-Whitney U test (for two groups) or the Kruskal-Wallis rank sum test (for a larger number of groups) - the homogeneity of variance was checked by Levene's test. For discrete parameters, the frequency of the feature occurrence in groups was analyzed with the $\chi^{2}$ df test with the appropriate number of degrees of freedom df $(\mathrm{df}=(\mathrm{m}-1) \times(\mathrm{n}-1)$, where $\mathrm{m}$-number of rows and $\mathrm{n}$-number of columns $) . p \leq 0.05$ was considered statistically significant. Statistical analysis was performed with the use of EPIINFO Ver. computer statistical software packages. 7.1.1.14 and Statistica Ver. 13.3.

\section{Results}

Amongst 2747 verified medical charts, 1832 belonged to female and 915 to male patients. Patients were aged between 1 month and 93 years, with the median age of 60 years, for women -62 years and for men -53 years, respectively (Table 1 ).

Table 1. Total sample description.

\begin{tabular}{ccc}
\hline & Number of Patients & Median Age [Years] \\
\hline Total & 2747 & 60 \\
\hline Women & $1832(66.7 \%)$ & 62 \\
\hline Man & $915(33.3 \%)$ & 63 \\
\hline
\end{tabular}

In total, 99 different diagnoses of oral mucosa lesions were found. After statistical analysis, 22 of the most frequent oral mucosa conditions were extracted. Diagnoses that were found in less than $1 \%$ of all of our patients, in which $1 \%$ equals less than 28 diagnoses, were assumed as less frequent. Those 22 frequent lesions comprised $83.8 \%$ of all of the studied oral cavity charts, equaling 2301 patients. Table 2 shows the distribution of diagnosed of 22 of the most frequent oral conditions.

The main reason of referral to the oral pathology outpatient clinic was oral lichen planus (OLP) in white striated or white atrophic form $(11.8 \%)$, which was also the most frequently found lesion among women (14.6\%). In men, it was the third-most common complain $(6.1 \%)$, after fibroma $(9,6 \%)$ and leukoplakia $(7.1 \%)$. For females, fibroma was the second-most frequent oral condition $(7.7 \%)$, as well as for the entire studied population $(8.3 \%)$. For both the entire study group and women, oral candidiasis was the third-most common pathology, $6.7 \%$ and $7.6 \%$, respectively. While in men, oral candida infection happened to be the eight, and it was diagnosed in 43 (4.7\%) male outpatients. On the other 
hand, leukoplakia was the fourth-most common diagnosis for the entire group (6.4\%) and fifth for women $(6.1 \%)$. More details are shown in Table 2.

Table 2. Twenty-two of the most frequently diagnosed oral mucosa lesions (OMLs) and its distribution among patients.

\begin{tabular}{|c|c|c|c|c|c|c|c|c|c|}
\hline \multirow[b]{2}{*}{ Oral Mucosa Lesions } & \multicolumn{3}{|c|}{$\begin{array}{c}22 \text { OMLs } n=2301 \\
83.8 \% \text { of the Whole Sample }\end{array}$} & \multicolumn{3}{|c|}{$\begin{array}{c}\text { Women } n=1546 \\
84.4 \% \text { of the Whole Sample }\end{array}$} & \multicolumn{3}{|c|}{$\begin{array}{c}\text { Men } n=755 \\
82.5 \% \text { of the Whole Sample }\end{array}$} \\
\hline & No. & $\begin{array}{l}\text { \% of the } \\
\text { Whole } \\
\text { Sample }\end{array}$ & $\begin{array}{c}\text { Age } \\
\text { Median }\end{array}$ & No. & $\begin{array}{l}\text { \% of the } \\
\text { Whole } \\
\text { Sample }\end{array}$ & $\begin{array}{c}\text { Age } \\
\text { Median }\end{array}$ & No. & $\begin{array}{l}\text { \% of the } \\
\text { Whole } \\
\text { Sample }\end{array}$ & $\begin{array}{c}\text { Age } \\
\text { Median }\end{array}$ \\
\hline $\begin{array}{l}\text { OLP/OLL (white and } \\
\text { white-atrophic forms) }\end{array}$ & 324 & 11.8 & 62.0 & 268 & 14.6 & 62.5 & 56 & 6.1 & 60.0 \\
\hline Fibroma & 229 & 8.3 & 60.0 & 141 & 7.7 & 60.0 & 88 & 9.6 & 63.0 \\
\hline Oral candidiasis & 183 & 6.7 & 67.0 & 140 & 7.6 & 67.0 & 43 & 4.7 & 63.0 \\
\hline Leukoplakia & 176 & 6.4 & 54.5 & 111 & 6.1 & 57.0 & 65 & 7.1 & 51.0 \\
\hline $\begin{array}{l}\text { Traumatic lesions } \\
\text { (ulcers, erosions) }\end{array}$ & 172 & 6.3 & 58.0 & 117 & 6.4 & 61.0 & 55 & 6.0 & 46.0 \\
\hline BMS & 145 & 5.3 & 67.0 & 108 & 5.9 & 67.0 & 37 & 4.0 & 66.0 \\
\hline Aphthae & 135 & 4.9 & 35.0 & 83 & 4.5 & 39.0 & 52 & 5.7 & 23.0 \\
\hline Denture stomatitis & 112 & 4.1 & 69.0 & 73 & 4.0 & 71.0 & 39 & 4.3 & 65.0 \\
\hline Mucocele & 105 & 3.8 & 36.0 & 51 & 2.8 & 39.0 & 54 & 5.9 & 30.0 \\
\hline Geographic tongue & 101 & 3.7 & 57.0 & 64 & 3.5 & 59.0 & 37 & 4.0 & 50.0 \\
\hline Hairy tongue & 95 & 3.4 & 53.0 & 45 & 2.5 & 58.0 & 50 & 5.5 & 45.0 \\
\hline Morsicatio buccarum & 83 & 3.0 & 43.0 & 54 & 3.0 & 51.0 & 29 & 3.2 & 26.0 \\
\hline Glossodynia & 66 & 2.4 & 63.0 & 47 & 2.6 & 63.0 & 19 & 2.1 & 68.0 \\
\hline Epulis & 63 & 2.3 & 47.0 & 44 & 2.4 & 54.5 & 19 & 2.1 & 33.0 \\
\hline $\begin{array}{c}\text { OLP/OLL } \\
\text { (erosive/bullous forms) }\end{array}$ & 62 & 2.2 & 66.0 & 47 & 2.6 & 67.0 & 15 & 1.6 & 65.0 \\
\hline Papilloma & 52 & 1.9 & 47.5 & 24 & 1.3 & 58.5 & 28 & 3.1 & 43.0 \\
\hline Gingival enlargement & 38 & 1.4 & 37.5 & 20 & 1.1 & 49.5 & 18 & 2.0 & 33.0 \\
\hline Hemangioma & 36 & 1.3 & 64.5 & 16 & 0.9 & 64.5 & 20 & 2.2 & 64.5 \\
\hline Xerostomia & 34 & 1.2 & 70.5 & 26 & 1.4 & 68.0 & 8 & 0.9 & 75.0 \\
\hline $\begin{array}{c}\text { Frictional } \\
\text { hyperkeratosis }\end{array}$ & 32 & 1.2 & 59.5 & 23 & 1.3 & 57.0 & 9 & 1.0 & 62.0 \\
\hline Angular cheilitis & 29 & 1.0 & 67.0 & 23 & 1.3 & 67.0 & 6 & 0.7 & 68.0 \\
\hline $\begin{array}{l}\text { Desquamative } \\
\text { gingivitis }\end{array}$ & 29 & 1.0 & 57.0 & 21 & 1.1 & 58.0 & 8 & 0.9 & 49.0 \\
\hline
\end{tabular}

OLP—oral lichen planus, OLL—oral lichenoid lesions, and BMS—burning mouth syndrome.

The sex distribution in the researched group of the 22 most frequent OMLs differed significantly $(p=0,00)$. In almost all, out of the 22 diagnosed oral mucosa conditions, the share of women was statistically higher than that of men, apart from lesions such as hemangioma, papilloma, hairy tongue and mucocele, where men were diagnosed more often. (Table 3).

Patients age in relation to the OMLs presence is important and worth discussing as it describes this connection. It can be confirmed that some oral mucosa pathologies are characteristic for younger, middle or older ages.

The age of studied outpatients was also statistically different $(p=0,00)$. Patients suffering from xerostomia where the oldest (70.5 years old), while patients referring due to aphthae were the youngest among the entire group ( 35 years old), as seen in Figure 1. In women, the oldest patients were the ones with denture stomatitis (71 years old), and the youngest were those suffering from aphthae and mucocele (39 years old). Men with aphthae were also significantly younger ( 23 years old), and xerostomia was the condition troubling the oldest men ( 75 years old). 
Table 3. The most frequent oral mucosa lesions (OMLs) in 2301 patients in relation with sex.

\begin{tabular}{|c|c|c|}
\hline \multirow[t]{2}{*}{22 Most Frequent OMLs } & \multicolumn{2}{|c|}{ Total $2301-100 \%$} \\
\hline & Female $67.2 \%$ & Male $32.8 \%$ \\
\hline $\begin{array}{l}\text { 1.OLP/OLL (white and white-atrophic } \\
\text { forms) }\end{array}$ & $82.7 \%$ & $17.3 \%$ \\
\hline 2.Fibroma & 61.6 & 38.4 \\
\hline 3.Oral candidiasis & 76.5 & 23.5 \\
\hline 4.Leukoplakia & 63.1 & 36.9 \\
\hline 5.Traumatic lesions (ulcers, erosions) & 68.0 & 32.0 \\
\hline 6.BMS & 74.5 & 25.5 \\
\hline 7.Aphthae & 61.5 & 38.5 \\
\hline 8.Denture stomatitis & 65.2 & 34.8 \\
\hline 9.Mucocele & 48.6 & 51.4 \\
\hline 10.Geographic tongue & 63.3 & 36.6 \\
\hline 11.Hairy tongue & 47.4 & 52.6 \\
\hline 12.Morsicatio buccarum & 65.1 & 34.9 \\
\hline 13.Glossodynia & 71.2 & 28.8 \\
\hline 14.Epulis & 69.8 & 30.2 \\
\hline 15.OLP/OLL (erosive/bullous forms) & 75.8 & 24.2 \\
\hline 16.Papilloma & 46.1 & 53.9 \\
\hline 17.Gingival enlargement & 52.6 & 47.3 \\
\hline 18.Hemangioma & 44.4 & 55.6 \\
\hline 19.Xerostomia & 76.5 & 23.5 \\
\hline 20.Frictional hyperkeratosis & 71.9 & 28.1 \\
\hline 21.Angular cheilitis & 79.3 & 20.7 \\
\hline 22.Desquamative gingivitis & 72.4 & 27.6 \\
\hline
\end{tabular}

$\chi^{2}{ }_{21}=116.5, p=0.00$; OLP—oral lichen planus, OLL—oral lichenoid lesions, and BMS—burning mouth syndrome.

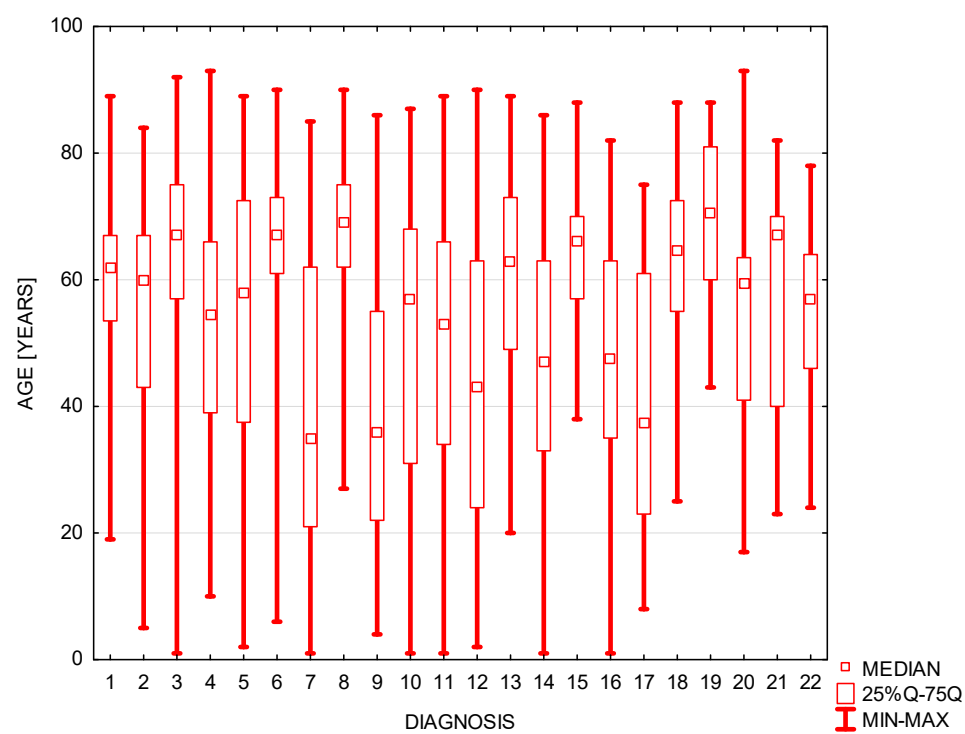

Figure 1. Age distribution of the patients in each oral mucosa diagnosis. The Kruskal-Wallis signed rank test $p=0.00$. The numbers on the diagnosis axis refer to the number and associated diagnosis from Table 3.

Table 4 depicts the relationship between the age of patients and the 22 most common diagnoses. 
Table 4. Relation between the age of the patients and the most frequent diagnoses.

\begin{tabular}{|c|c|c|c|c|c|c|c|c|c|c|c|c|c|c|c|c|c|c|c|c|c|}
\hline $\begin{array}{l}\text { Age of the } \\
\text { Patients }\end{array}$ & $\underset{\text { White }}{\text { OLP/OLL }}$ & Fibroma & $\begin{array}{c}\text { Oral } \\
\text { Candidi- } \\
\text { asis }\end{array}$ & Leukoplakia & $\begin{array}{c}\text { Traumatic } \\
\text { Lesion }\end{array}$ & BMS & Aphthae & $\begin{array}{c}\text { Denture } \\
\text { St. }\end{array}$ & Mucocele & $\begin{array}{l}\text { Geographic } \\
\text { T. }\end{array}$ & Hairy $\mathrm{T}$. & $\begin{array}{l}\text { Morsicatio } \\
\text { Bucc. }\end{array}$ & Glossodynia & Epulis & $\begin{array}{c}\text { Erosive } \\
\text { OLP/OLL }\end{array}$ & Papilloma & $\begin{array}{c}\text { Gingival } \\
\text { enlar. }\end{array}$ & Hemangioma & Xerostomia & $\begin{array}{c}\text { Fric. } \\
\text { Hyperk- } \\
\text { eratosis }\end{array}$ & $\begin{array}{l}\text { Angular } \\
\text { Cheilitis }\end{array}$ \\
\hline Fibroma & 0.03 & & & & & & & & & & & & & & & & & & & & \\
\hline $\begin{array}{c}\text { Oral } \\
\text { candidiasis }\end{array}$ & 0.00 & 0.00 & & & & & & & & & & & & & & & & & & & \\
\hline $\begin{array}{l}\text { candidasiss } \\
\text { Leukoplakia }\end{array}$ & 0.00 & 0.06 & 0.00 & & & & & & & & & & & & & & & & & & \\
\hline $\begin{array}{l}\text { Traumatic } \\
\text { lesion }\end{array}$ & 0.01 & 0.49 & 0.00 & 0.72 & & & & & & & & & & & & & & & & & \\
\hline $\begin{array}{l}\text { lession } \\
\text { BMS }\end{array}$ & 0.00 & 0.00 & 0.76 & 0.00 & 0.00 & & & & & & & & & & & & & & & & \\
\hline $\begin{array}{l}\text { Aphthae } \\
\text { Denture }\end{array}$ & 0.00 & 0.00 & 0.00 & 0.00 & 0.00 & 0.00 & & & & & & & & & & & & & & & \\
\hline $\begin{array}{l}\text { Denture } \\
\text { Stomatitis }\end{array}$ & 0.00 & 0.00 & 0.03 & 0.00 & 0.00 & 0.09 & 0.00 & & & & & & & & & & & & & & \\
\hline $\begin{array}{l}\text { Mucocele } \\
\text { Suls }\end{array}$ & 0.00 & 0.00 & 0.00 & 0.000 & 0.00 & 0.00 & 0.86 & 0.00 & & & & & & & & & & & & & \\
\hline $\begin{array}{l}\text { Geographic } \\
\text { Tongue }\end{array}$ & 0.00 & 0.05 & 0.00 & 0.32 & 0.19 & 0.00 & 0.00 & 0.00 & 0.00 & & & & & & & & & & & & \\
\hline $\begin{array}{l}\text { Hairy Tongue } \\
\text { Tongue }\end{array}$ & 0.00 & 0.01 & 0.00 & 0.16 & 0.10 & 0.00 & 0.00 & 0.00 & 0.00 & 0.69 & & & & & & & & & & & \\
\hline $\begin{array}{l}\text { Morricatio } \\
\text { Buccarum }\end{array}$ & 0.00 & 0.00 & 0.00 & 0.00 & 0.00 & 0.00 & 0.09 & 0.00 & 0.06 & 0.03 & 0.10 & & & & & & & & & & \\
\hline $\begin{array}{l}\text { Glossodynia } \\
\text { Eppulis }\end{array}$ & 0.31 & $\begin{array}{l}0.04 \\
0.00\end{array}$ & 0.23 & $\begin{array}{l}0.00 \\
0.03\end{array}$ & $\begin{array}{l}0.03 \\
0.02\end{array}$ & $\begin{array}{l}0.13 \\
0.00\end{array}$ & $\begin{array}{l}0.00 \\
0.01\end{array}$ & $\begin{array}{l}0.00 \\
0.00\end{array}$ & $\begin{array}{l}0.00 \\
0.01\end{array}$ & $\begin{array}{l}0.00 \\
0.29\end{array}$ & 0.00 & 0.00 & & & & & & & & & \\
\hline $\begin{array}{l}\text { Epulis } \\
\text { Erosive }\end{array}$ & 0.00 & $\begin{array}{l}0.00 \\
0.00\end{array}$ & $\begin{array}{l}0.00 \\
0.57\end{array}$ & 0.03 & 0.02 & $\begin{array}{l}0.00 \\
0.43\end{array}$ & 0.01 & 0.00 & 0.01 & 0.29 & 0.44 & 0.43 & 0.00 & 000 & & & & & & & \\
\hline $\begin{array}{l}\text { OLP/OLL } \\
\text { Papilloma }\end{array}$ & $\begin{array}{l}0.01 \\
0.00\end{array}$ & 0.01 & 0.00 & $\begin{array}{l}0.12 \\
0.12\end{array}$ & $\begin{array}{l}0.00 \\
0.06\end{array}$ & $\begin{array}{l}.43 \\
0.00\end{array}$ & $\begin{array}{l}0.00 \\
0.01\end{array}$ & $\begin{array}{l}0.02 \\
0.00\end{array}$ & $\begin{array}{l}0.00 \\
0.01\end{array}$ & $\begin{array}{l}0.00 \\
0.46\end{array}$ & $\begin{array}{l}0.00 \\
0.69\end{array}$ & & $\begin{array}{l}0.45 \\
0.00\end{array}$ & 0.84 & 0.00 & & & & & & \\
\hline $\begin{array}{l}\text { Papilloma } \\
\text { Gingival }\end{array}$ & 0.00 & & 0.00 & 0.00 & & & & $\begin{array}{l}0.00 \\
0.00\end{array}$ & $\begin{array}{l}0.01 \\
0.36\end{array}$ & 0.46 & 0.69 & $\begin{array}{l}0.38 \\
0.59\end{array}$ & 0.00 & 0.84 & 0.00 & & & & & & \\
\hline Enlargement & 0.00 & 0.00 & 0.00 & 0.00 & 0.00 & 0.00 & 0.50 & 0.00 & 0.36 & 0.02 & 0.06 & 0.59 & 0.00 & 0.23 & 0.00 & 0.23 & & & & & \\
\hline $\begin{array}{c}\text { Hemangioma } \\
\text { Xerostomia }\end{array}$ & $\begin{array}{l}0.18 \\
0.00\end{array}$ & $\begin{array}{l}0.06 \\
0.00\end{array}$ & $\begin{array}{l}0.45 \\
0.08\end{array}$ & $\begin{array}{l}0.00 \\
0.00\end{array}$ & $\begin{array}{l}0.04 \\
0.00\end{array}$ & $\begin{array}{l}0.265 \\
0.144\end{array}$ & $\begin{array}{l}0.00 \\
0.00\end{array}$ & $\begin{array}{l}0.04 \\
0.65\end{array}$ & $\begin{array}{l}0.00 \\
0.00\end{array}$ & $\begin{array}{l}0.01 \\
0.00\end{array}$ & $\begin{array}{l}0.01 \\
0.00\end{array}$ & $\begin{array}{l}0.00 \\
0.00\end{array}$ & $\begin{array}{l}0.832 \\
0.02\end{array}$ & $\begin{array}{l}0.00 \\
0.00\end{array}$ & $\begin{array}{l}0.65 \\
0.06\end{array}$ & $\begin{array}{l}0.00 \\
0.00\end{array}$ & $\begin{array}{l}0.00 \\
0.00\end{array}$ & 0.06 & & & \\
\hline $\begin{array}{c}\text { Frictional } \\
\text { Hyperkeratosis }\end{array}$ & 0.02 & 0.23 & 0.00 & 0.97 & 0.87 & 0.00 & 0.00 & 0.00 & 0.00 & 0.82 & 0.42 & 0.03 & 0.04 & 0.13 & 0.00 & 0.20 & 0.01 & 0.02 & 0.00 & & \\
\hline $\begin{array}{l}\text { Angular } \\
\text { Cheilitis }\end{array}$ & 0.15 & 0.13 & 0.45 & 0.05 & 0.19 & 0.47 & 0.00 & 0.06 & 0.00 & 0.03 & 0.01 & 0.00 & 0.99 & 0.01 & 0.72 & 0.01 & 0.00 & 0.95 & 0.07 & 0.03 & \\
\hline $\begin{array}{l}\text { Desquam. } \\
\text { Gingivitis }\end{array}$ & 0.02 & 0.44 & 0.00 & 0.42 & 0.99 & 0.00 & 0.00 & 0.00 & 0.00 & 0.56 & 0.28 & 0.02 & 0.04 & 0.08 & 0.00 & 0.16 & 0.01 & 0.03 & 0.00 & 0.84 & 0.06 \\
\hline
\end{tabular}

Test U Mann-Whitney; OLP—oral lichen planus, OLL—oral lichenoid lesions, BMS—-burning mouth syndrome. 
In addition, patients suffering from denture stomatitis (69 years old) were in the oldest group (women $71 \mathrm{y} / \mathrm{o}$, men $65 \mathrm{y} / \mathrm{o}$ ).

The groups of patients diagnosed with oral candida infection with the average age of 67 years (women $67 \mathrm{y} / \mathrm{o}$, men $63 \mathrm{y} / \mathrm{o}$ ) were significantly younger than those suffering from denture stomatitis.

People suffering from BMS were also in the elder patients' group with the average age at 67 years (women $67 \mathrm{y} / \mathrm{o}$, men $66 \mathrm{y} / \mathrm{o}$ ). The next group diagnosed with hemangioma was a little younger with the median age 64.5 years for all of the research groups. In turn, glossodynia was the problem in patients at the median age of 63 years (women $63 \mathrm{y} / \mathrm{o}$, men $68 \mathrm{y} / \mathrm{o}$ ), and the median age of patients diagnosed with white or white-atrophic OLP was similar in this older group -62 years, $(62.5 \mathrm{y} / \mathrm{o}$ and $60 \mathrm{y} / \mathrm{o}$ for women and men, respectively).

Fibroma diagnosis was related with a slightly younger age of subjects, the median age for the entire group and for women was $60 \mathrm{y} / \mathrm{o}$, and for men $63 \mathrm{y} / \mathrm{o}$. Even more younger patients aged 60-50 years were present in the group with frictional hyperkeratosis (59.5, 57,62 years old in the entire group, women and men, respectively), with traumatic oral mucosa lesions (58,61, and 46 years old in the entire group, women and men, respectively), with geographic tongue $(57,59$, and 50 years old in the entire group, women and men, respectively), with leukoplakia $(54.5,57$, and 51 years old in the entire group, women and men, respectively) and with hairy tongue $(53,58$, and 45 years old in the entire group, women and men, respectively). Younger patients with the average age between the 50 and 40 years were in the groups with: papilloma (47.5 years old in the entire group, $58.5 \mathrm{y} / \mathrm{o}$, $43 \mathrm{y} / \mathrm{o}$ women and men, respectively), epulis (47 years old in the entire group, $54.5 \mathrm{y} / \mathrm{o}$ women and $33 \mathrm{y} / \mathrm{o}$ men), and morsicatio buccarum (43 years old in the entire group, 51 y/o, 26 y/o women and men, respectively) diagnoses.

Finally, the youngest group of patients represented gingival enlargement $(37.5,49.5$ and 33 years old in the entire group, women and men, respectively), mucocele $(36,39$ and 30 years old in the entire group, women and men, respectively) and aphthae $(35,39$, 23 years old in the entire group, women and men, respectively) diagnoses.

\section{Discussion}

In this study, the overall prevalence of oral mucosal lesions was found to be higher in older than in younger patients. As much as 53\% of patients from the group of 22 described diagnoses were 60 years old or above. Similarly, in the study of Alshayeb et al. [27], the oral lesions were more common among patients older than $50 \mathrm{y} / \mathrm{o}$. The study of 6267 randomly selected subjects from Pomerania-Germany showed age-dependent prevalence of oral mucosa lesions-with 5.56\% in younger (20-29) and 19.55\% in older (70-81 y/o) people [6]. By contrast, in the study of 1976 individuals from South Africa, the male population of participants aged 25-34 had a higher prevalence of OML. In the other study that comprised of 21,500 outpatients, the results were different. Oral disorders prevalence was higher in younger group: aged 31-50 years than in patients being $50 \mathrm{y} / \mathrm{o}$ and above [28].

In our study, the age median was the highest in patients with xerostomia, burning mouth syndrome, angular cheilitis and oral candidiasis. The youngest median age was observed in patients with aphthae, mucocele and gingival enlargement. The higher OMLs frequency was related with the female gender. In Kumar et al., investigation prevalence, according to the gender, was reported to be higher in the male group [28]. In addition, Patil et al. [7] and Splieth et al. [6] described males as more frequently affected than females but without a significant difference. Other investigation from Ajman-UAE, highlighted a clearly greater ratio of the oral lesions among smoking male patients versus female-73\% vs. $27 \%$, respectively [27]. In another study, the OMLs presence was found to be higher in older patients [29-31] and correlated to females [32]. Kansky et al. [33] showed the equal presence of oral mucosa lesions in both genders.

In our study, oral lichen planus (OLP) and oral lichenoid lesions (OLL) were grouped as oral lichenoid diseases because some of our patients had been using different medica- 
tions that were described in the literature as potentially causative for OLL development. In our research, the most frequently recognized lichenoid diseases/lesions were white forms (11.8\% of all medical diagnoses), and additionally, in $2.2 \%$ of all made diagnoses an erosive/bullous forms was recognized, making it altogether $14 \%$. For women, this prevalence was even higher-17.2\%. It is worth emphasizing that these oral lesions were accompanied by the involvement of the other sites such as: skin or nonoral mucosa, only in about $6 \%$, and have been under clinical control for at least 8 years. In other studies [34-37], the prevalence of lichen lesions was only at the rate of $1.3 \%, 1.2 \%$ and $0.8 \%$, accordingly. However, it should be pointed out, that cited authors described the India population from different geographical regions, cultures and habits. In turn, a higher prevalence of OLP lesions, at the level of $2.3 \%, 2.5 \%, 3.5 \%$ and $5.6 \%$, was observed by authors from Slovenia [38], Italy [39], Northern Finland [40] and from Egypt [4], respectively. In the article by Oivio et al. [40], the birth cohort study of 1961 participants, oral lichenoid diseases were described as more frequent in men. Oral lichenoid diseases, both OLL and OLP, mainly manifest as symmetrical lesions, on both sites of the oral cavity. However, when the triggering factor of OLL is a local irritation (mechanical trauma and toxic factor), the lesion is observed only on adjacent oral mucosa [5,25] (Figures 2 and 3).

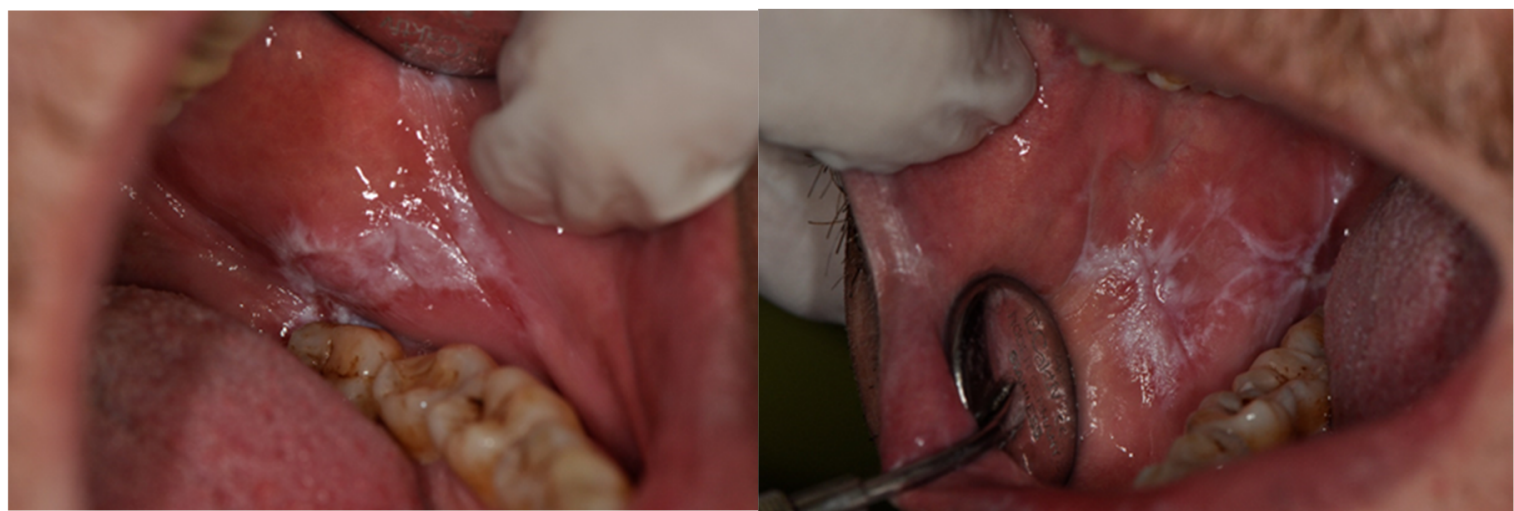

Figure 2. Bilateral oral lichen planus observed on the right and left buccal oral mucosa.

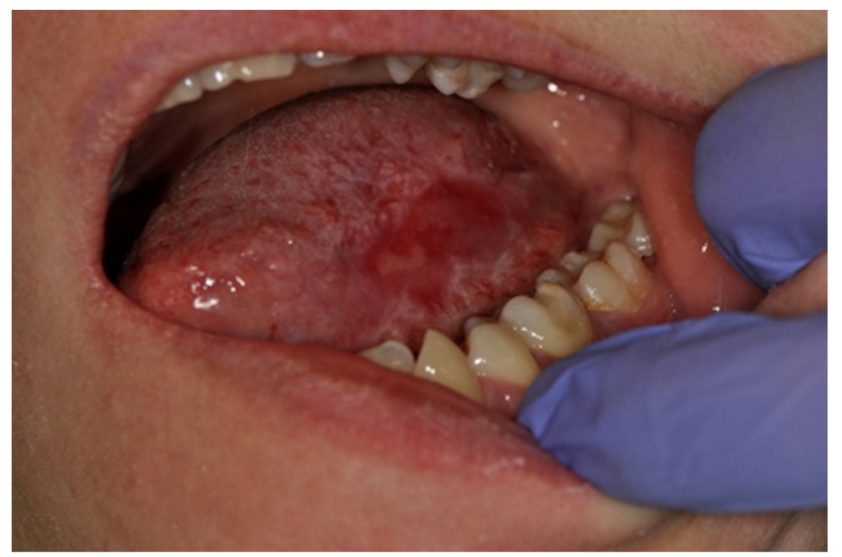

Figure 3. Unilateral oral lichen planus, observed only on the left side of the tongue.

The second most common lesion was benign overgrowth-fibroma- $8.3 \%$, with a higher prevalence in men than women in the whole study group. A similar incidence of $8.7 \%$ was reported by Kansky et al. [33] in a group of 2395 patients attending general dental practice with various, not only oral mucosa, problems. Traumatic fibroma prevalence at the level of $4.5 \%$ was described in the group of 231 general dental patients investigated by Toum et al. [41] These lesions are presented usually as secondary to local injury, inflammation or are closely related to different parafunctions. Assessing different reactive lesions, Babu and Hallikeri [42] found fibrous hyperplasia in $47 \%$ of 659 cases and more frequently in 
females. Our outcomes were similar, because a higher fibroma prevalence, $61.6 \%$, was observed in women in the separate group of 22 diagnoses. Fibromas are presented as single, nonsymmetrical nodules, and sometimes, their development is related with mechanical irritation [11]. (Figure 4)

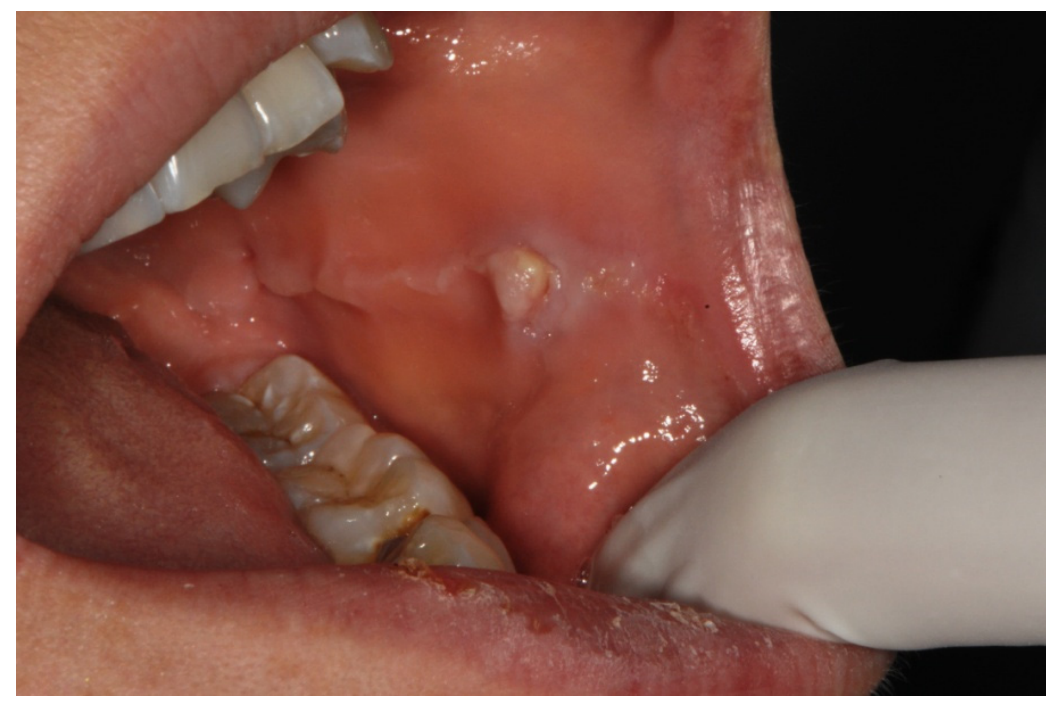

Figure 4. Fibroma caused by mechanical irritation and parafunctional biting of buccal mucosa.

Oral candidiasis was the third-most common pathology. Prevalence was $6.7 \%$ in the whole group and was higher in females, both in the entire group and in the group of 22 diagnoses. Kumar et al. [34] found this infection in 8\%, with the same level in both sexes. In earlier work from India, from 2008, oral candidiasis was described in only $1.3 \%$ of 1190 outpatients [35]. Candidiasis is the most frequent infection of the oral cavity. It is well known that oral cavity is the principal Candida spp. reservoir, and about $40-60 \%$ of the world population is colonized by these fungi. In beneficial conditions, symptomatic Candida infection can be developed. The pathogenesis of this infection is related to different predisposing factors: both local, such as reduced salivary flow, use of dentures, and bad oral hygiene; and systemic factors, such as immunosuppression or endocrine disorders. In the study of 125 removable prosthesis wearers [13], Candida infection was present only in two cases. Thus, the differences in the prevalence of this pathology can be related with the presence of predisposing conditions. In our work, we did not take these factors into consideration.

The incidence of leukoplakia varies among numerous scientific studies, and a comprehensive global review point of its prevalence is $2.6 \%$ [43]. In our study, this lesion was present in $6.4 \%$, of the entire group and was more frequently seen in men in the whole group. However, in the 22 assessed pathologies, leukoplakia was diagnosed at a significantly higher level in women than in men. A similar result of $5.1 \%$ was shown in the study by Lebanon [41]. Other authors described the presence of this lesion in various degrees of prevalence: $2.85 \%$ [6], 3.1\% [34] and only $0.5 \%$, but twice more often in males [40]. In addition, Kumar highlighted the strong association of leukoplakia with the male gender [28]. In the South African population, leukoplakia was present in 19\% [44].

There is a known significant correlation between tobacco smoking and the presence of oral leukoplakia. Kusiak et al. [45] in the group of 416 subjects with leukoplakia found its highest incidence in the age group of $41-60$ years. In addition, in $85.1 \%$ cases, they were active smokers. In the next study of 54 smoking patients, leukoplakia was present in $8.1 \%$ [27].

According to the geographical region and type of leukoplakia, this pathology can be present in the oral cavity in different configurations. Mostly, it can be seen bilaterally on the buccal mucosa or on the floor of the mouth [7,43,45] (Figure 5). 


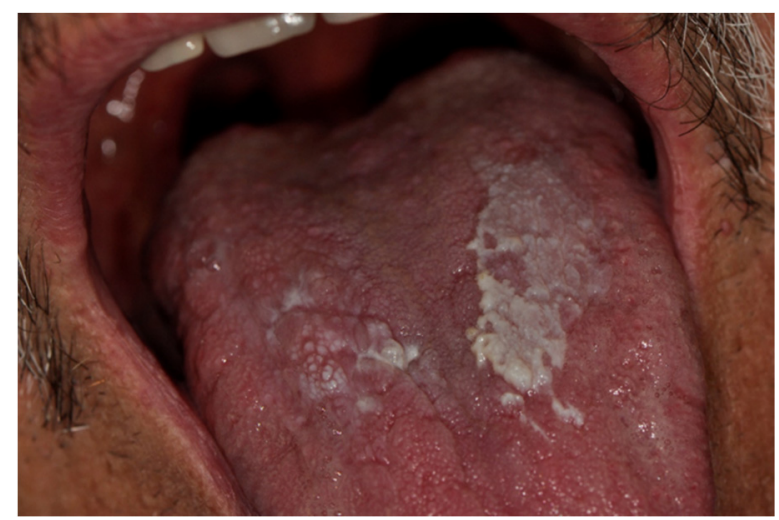

Figure 5. Leukoplakia placed symmetrically on the dorsal surface of the tongue.

In our study, the lesions of traumatic origin, such as erosions and ulcers, were seen in $6,3 \%$ cases. These lesions develop mainly as single-site pathologies, due to the close connection with the acting-causative factor [11] (Figure 6).

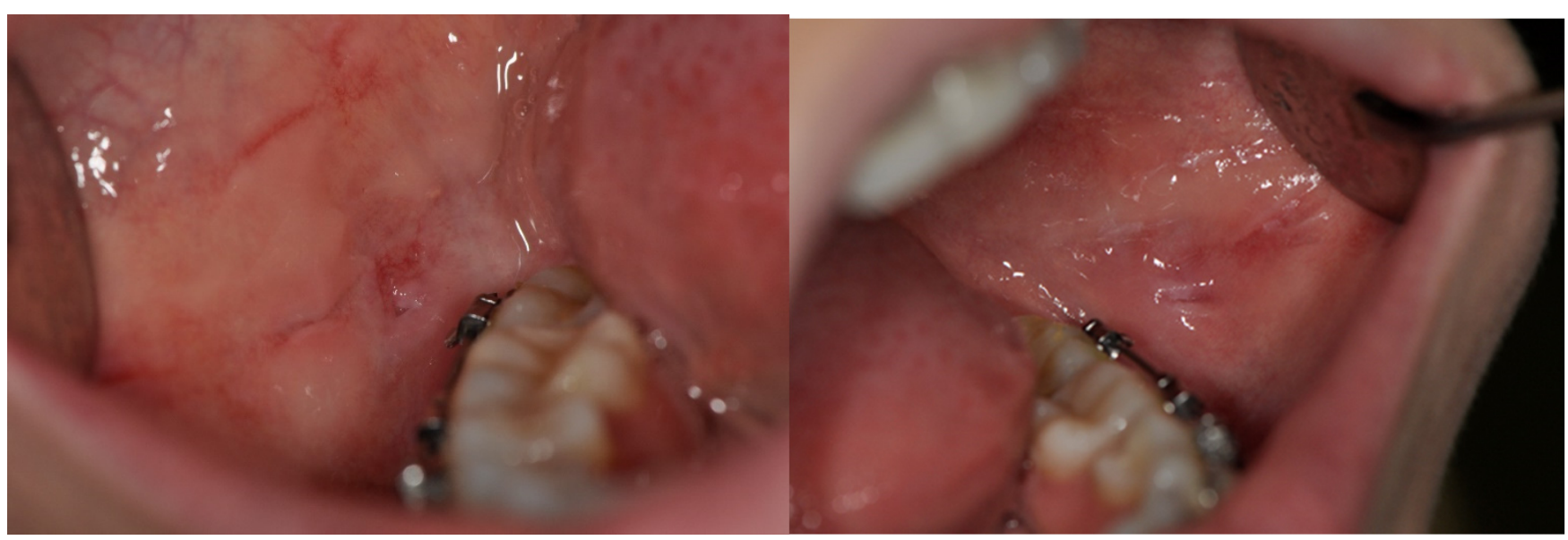

Figure 6. Mechanical trauma of the right and left buccal mucosa due to orthodontic appliance.

The next OMLs such as BMS, aphthae, denture stomatitis, mucocele, geographic tongue, hairy tongue and morsicatio buccarum were seen in at a lower prevalence-from $5,3 \%$ to $3,0 \%$, as seen in Figure 7 .

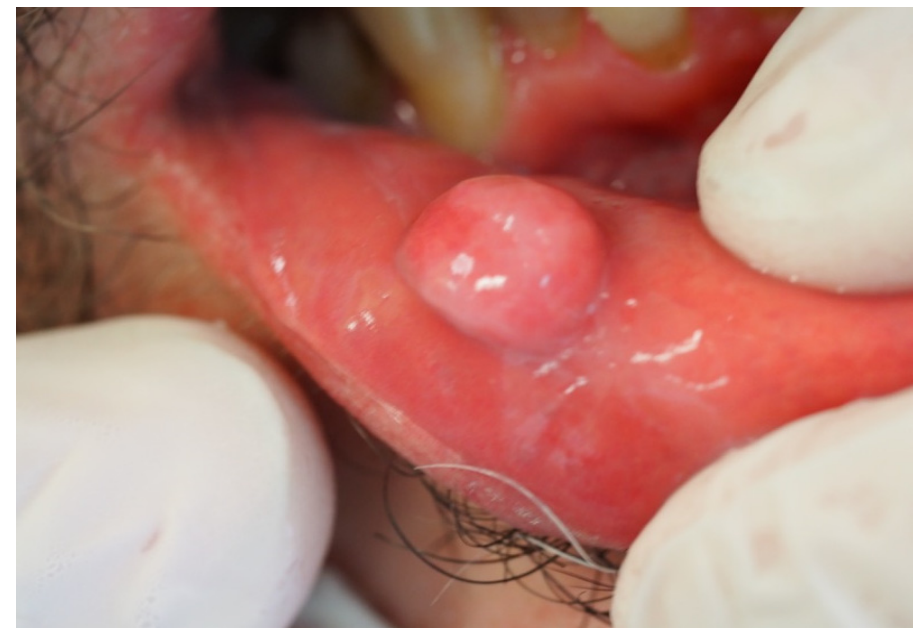

Figure 7. Mucocele-right lower lip. 
In our study, the lesions of traumatic origin, such as erosions and ulcers, were the next frequently seen $6.3 \%$ of cases. The next OMLs such as BMS, aphthae, denture stomatitis, mucocele, geographic tongue, hairy tongue and morsicatio buccarum were observed at a lower prevalence from $5.3 \%$ to $3.0 \%$. The other lesions present from $2.4 \%$ to $1.0 \%$ were: glossodynia, epulis, papilloma, gingival enlargement, hemangioma, xerostomia, frictional keratosis, angular cheilitis and desquamative gingivitis.

This work evaluated the types and prevalence of oral mucosa conditions in the group of patients already seeking professional help, due to its presence. We also analyzed the prevalence of these lesions only in the connection with sex and age, without taking into consideration other, e.g., general factors or habits. The results of our work might differ from those achieved by other researchers, because each of our patients already had an oral mucosa lesion. Therefore, the OMLs frequency was not assessed in the general population, which may be considered as the weakness of this work. Nevertheless, the similar assessment of OMLs presence in 277 older people was published by Rivera et al. [46]. The most frequent lesions in patients, aged 61-97 y/o with mean age $70.4 \mathrm{y} / \mathrm{o}$, were also almost the same: fibroma, hemangioma, BMS and OLP.

Our results depict the frequency of different oral mucosa conditions within the group of these pathologies. Results also describe the relationship between the age and diagnosed pathologies. In the whole study group, there was significantly higher number of females; therefore, the frequency of many pathologies was higher in women. However, it should be observed that in the group of 22 diagnoses among 2301 patients, where there were also significantly more women, the higher number of mucocele, hairy tongue, papilloma and hemangioma was diagnosed in men.

\section{Conclusions}

The present study has provided the observation about the aspects and types of oral mucosa lesion prevalence in patients visiting oral pathology outpatient clinic. The most frequent pathology was OLP/OLL. The majority of oral mucosa lesions were observed more often in women, apart from mucocele, hairy tongue, papilloma and hemangioma which were affecting men more often. In our research, the age median was the highest in patients with xerostomia, BMS, angular cheilitis and oral candidiasis. On the other hand, the youngest were affected by: aphthae, mucocele and gingival enlargement.

Clinical presentations of OMLs sometimes may be misleading, because the manifestations of the lesion can be similar and resemble each other. It is important for clinicians to be familiar not only with distinctive features, which sometimes may not be clear, but also with its occurrence dependent on the gender and age of the patient. Oral mucosa lesions very often cause different signs and symptoms. These can provoke alterations in physiological functions of the oral cavity such as chawing, swallowing or even speaking. When someone uses only one site during chewing, due to a painful mucosal lesion, in a longer perspective, the unilateral overgrowth of masticatory muscles and the facial asymmetry can be developed and observed. This situation can also lead to one-sided dental wear, which in specific conditions may cause changings in the face symmetry. Different types of soft tissue tumors can interfere with speech and chewing. What is more, if the tumor is painless, only the face asymmetry, in the buccal region or lips, may give a clear image of the pathology and the accurate diagnosis can be made at the first sight. This work proves that oral mucosa lesions are present and diagnosed regardless of the patients' age.

It is crucial to observe and detect any face asymmetry at the beginning of the medical examination. It makes it easier and faster to detect any head and neck pathology.

\section{Keypoints}

- Clinicians should be familiar not only with distinctive features of OMLs, which sometimes may not be clear, but also with its population prevalence and with its frequency in connection to age and gender.

- In our study, oral lichen planus was the most frequent diagnosis. 
- In our study, women were more frequently affected by different types of OMLs, apart from mucocele, hairy tongue, papilloma and hemangioma, which affected men more often.

- In our research, the age median was the highest in patients with xerostomia, burning mouth syndrome, angular cheilitis and oral candidiasis.

- The youngest median age was observed in patients with aphthae, mucocele and gingival enlargement.

- According to the types and lesions pattern, oral mucosa pathologies are observed in different sites of oral cavity, both in single or multiple localizations and both symmetrically and non-symmetrically.

Author Contributions: Conceptualization, M.R.-O. and J.E.O.-D.; methodology, M.R.-O. and J.E.O.-D.; software, K.B. and I..S; validation, M.R.-O., J.E.O.-D., K.B. and I.S.; formal analysis, M.R.-O. and J.E.O.-D.; investigation, J.E.O.-D., K.B. and I.S.; resources, M.R.-O. and J.E.O.-D.; data curation, J.E.O.D., K.B. and I.S.; writing—original draft preparation, J.E.O.-D. and M.R.-O.; writing—review and editing, J.E.O.-D.; visualization, J.E.O.-D. and M.R.-O.; supervision, M.R.-O. and J.E.O.-D.; project administration, M.R.-O. and J.E.O.-D.; and funding acquisition, M.R.-O. All authors have read and agreed to the published version of the manuscript.

Funding: This research received no external funding.

Institutional Review Board Statement: Ethical review and approval were waived for this study, due to retrospective data used and no possibility to identify an individual person from the data that were collected from the medical files.

Informed Consent Statement: Oral informed consent was obtained from the patient(s) or his/her legal guardians to publish this paper.

Data Availability Statement: The data that support the findings of this study are available from the corresponding author, J.E.O.-D., upon reasonable request.

Conflicts of Interest: The authors declare no conflict of interest.

\section{References}

1. Mehrotra, V.; Devi, P.; Bhovi, T.V.; Jyoti, B.; Pradesh, U. Mouth as a Mirror of Systemic Diseases. Gomal J. Med. Sci. 2010, 8, 235-241.

2. Suliman, N.M.; Johannessen, A.C.; Ali, R.W.; Salman, H.; Åstrøm, A.N. Influence of oral mucosal lesions and oral symptoms on oral health related quality of life in dermatological patients: A cross sectional study in Sudan. BMC Oral Health 2012, 12, 19. [CrossRef] [PubMed]

3. Silverman, S. Mucosal Lesions in Older Adults. J. Am. Dent. Assoc. 2007, 138, S41-S46. [CrossRef] [PubMed]

4. El-Hamd, M.; Aboeldahab, S. Clinicoepidemiological analysis of patients with oral mucosal lesions attending dermatology clinics. Egypt. J. Dermatol. Venerol. 2018, 38, 73. [CrossRef]

5. Kamath, V.; Setlur, K.; Yerlagudda, K. Oral lichenoid lesions-A review and update. Indian J. Dermatol. 2015, 60, 102. [CrossRef]

6. Splieth, C.; Sümning, W.; Bessel, F.; John, U.; Kocher, T. Prevalence of oral mucosal lesions in a representative population. Quintessence Int. 2007, 38, 23-29. [PubMed]

7. Patil, P.; Bathi, R.; Chaudhari, S. Prevalence of oral mucosal lesions in dental patients with tobacco smoking, chewing, and mixed habits: A cross-sectional study in South India. J. Fam. Community Med. 2013, 20, 130. [CrossRef]

8. Saraswathi, T.; Ranganathan, K.; Shanmugam, S.; Sowmya, R.; Narasimhan, P.; Gunaseelan, R. Prevalence of oral lesions in relation to habits: Cross-sectional study in South India. Indian J. Dent. Res. 2006, 17, 121. [CrossRef]

9. Wong, T.; Yap, T.; Wiesenfeld, D. Common causes of 'swelling' in the oral cavity. Aust. J. Gen. Pract. 2020, 49, 575-580. [CrossRef]

10. Daley, T.D.; Armstrong, J.E. Oral Manifestations of Gastrointestinal Diseases. Can. J. Gastroenterol. 2007, 21, 241-244. [CrossRef]

11. Ariyawardana, A. Traumatic Oral Mucosal Lesions: A Mini Review and Clinical Update. Trauma. Oral Mucosal Lesions A Mini Rev. Clin. Updat. 2014, 13, 254-259.

12. Hermann, P.; Beck, A.; Fábián, G.; Fejérdy, P.; Fábián, T.K. Salivary defense proteins: Their network and role in innate and acquired oral immunity. Int. J. Mol. Sci. 2012, 13, 4295-4320. [CrossRef]

13. Pavičić, D.K.; Braut, A.; Pezelj-Ribarić, S.; Glažar, I.; Lajnert, V.; Mišković, I.; Muhvić-Urek, M. Predictors of oral mucosal lesions among removable prosthesis wearers. Period. Biol. 2017, 119, 181-187. [CrossRef]

14. Rocha Gusmão, J.M.; Ferreira Dos Santos, S.S.; Piero Neisser, M.; Cardoso Jorge, A.O.; Ivan Faria, M. Correlation between factors associated with the removable partial dentures use and Candida spp. in saliva. Gerodontology 2011, 28, 283-288. [CrossRef] 
15. Tadin, A.; Gavic, L.; Zeravica, A.; Ugrin, K.; Galic, N.; Zeljezic, D. Assessment of cytotoxic and genotoxic effects of conventional and whitening kinds of toothpaste on oral mucosa cells. Acta Odontol. Scand. 2018, 76, 64-70. [CrossRef]

16. Arunkumar, S.; Kalappanavar, A.N.; Annigeri, R.G.; Shakunthala, G.K. Adverse Oral Manifestations of Cardiovascular Drugs. IOSR J. Dent. Med. Sci. 2013, 7, 64-71. [CrossRef]

17. Pinna, R.; Cocco, F.; Campus, G.; Conti, G.; Milia, E.; Sardella, A.; Cagetti, M.G. Genetic and developmental disorders of the oral mucosa: Epidemiology; molecular mechanisms; diagnostic criteria; management. Periodontology 2000 2019, 80, 12-27. [CrossRef]

18. Schlosser, B.J.; Pirigyi, M.; Mirowski, G.W. Oral Manifestations of Hematologic and Nutritional Diseases. Otolaryngol. Clin. N. Am. 2011, 44, 183-203. [CrossRef]

19. Al Wayli, H.; Khalid Rashed, B.A.W.; Kumar, A.; Rastogi, S. The Prevalence of Oral Mucosal Lesions among Saudi Females Visiting a Tertiary Dental Health Center in Riyadh Region, Saudi Arabia. J. Int. Oral Heal. 2016, 8, 675-678. [CrossRef]

20. Mohan, R.P.S.; Verma, S.; Singh, U.; Agarwal, N. Acute primary herpetic gingivostomatitis. Case Rep. 2013, 2013 , bcr2013200074. [CrossRef]

21. Mravak-Stipetić, M.; Sabol, I.; Kranjčić, J.; Knežević, M.; Grce, M. Human Papillomavirus in the Lesions of the Oral Mucosa According to Topography. PLoS ONE 2013, 8, e69736. [CrossRef] [PubMed]

22. D'Souza, G.; Agrawal, Y.; Halpern, J.; Bodison, S.; Gillison, M.L. Oral sexual behaviors associated with prevalent oral human papillomavirus infection. J. Infect. Dis. 2009, 199, 1263-1269. [CrossRef] [PubMed]

23. Kusiak, A.; Jereczek-Fossa, B.A.; Cichońska, D.; Alterio, D. Oncological-Therapy Related Oral Mucositis as an Interdisciplinary Problem-Literature Review. Int. J. Environ. Res. Public Health 2020, 17, 2464. [CrossRef] [PubMed]

24. Hong, C.H.L.; Dean, D.R.; Hull, K.; Hu, S.J.; Sim, Y.F.; Nadeau, C.; Gonçalves, S.; Lodi, G.; Hodgson, T.A. World Workshop on Oral Medicine VII: Relative frequency of oral mucosal lesions in children, a scoping review. Oral Dis. 2019, 25, 193-203. [CrossRef]

25. Carrozzo, M.; Porter, S.; Mercadante, V.; Fedele, S. Oral Lichen Planus: A Disease or a Spectrum of Tissue Reactions? Types, Causes, Diagnostic Algorhythms, Prognosis, Management Strategies. Periodontology 2000, 80, 105-125. [CrossRef]

26. Karagöz, G.; Bektaş Kayhan, K.; Ünür, M. Desquamative Gingivitis: A Review. J. Istanb. Univ. Fac. Dent. 2016, 50. [CrossRef]

27. Alshayeb, M.; Mathew, A.; Varma, S.; Elkaseh, A.; Kuduruthullah, S.; Ashekhi, A.; Habbal, A.W.A.L. Prevalence and distribution of oral mucosal lesions associated with tobacco use in patients visiting a dental school in Ajman. Onkol. I Radioter. 2019, 46, 29-33.

28. Kumar, S.; Suhag, A.; Narwal, A.; Kolay, S.; Konidena, A.; Sachdev, A. Oral mucosal disorder-A demographic study. J. Fam. Med. Prim. Care 2020, 9, 755. [CrossRef]

29. Pratik, P.; Desai, V. Prevalence of habits and oral mucosal lesions in Jaipur, Rajasthan. Indian J. Dent. Res. 2015, 26, 196. [CrossRef]

30. Lin, H.C.; Corbet, E.F.; Lo, E.C.M. Oral Mucosal Lesions in Adult Chinese. J. Dent. Res. 2001, 80, 1486-1490. [CrossRef]

31. van der Waal, I. Diseases of the oral mucosa in the aged patient. Int. Dent. J. 1983, 33, 319-324. Available online: http: //www.ncbi.nlm.nih.gov/ pubmed/ 6581127 (accessed on 27 November 2021). [PubMed]

32. Al-Mobeeriek, A.; AlDosari, A.M. Prevalence of oral lesions among Saudi dental patients. Ann. Saudi Med. 2009, 29, 365-368. [CrossRef] [PubMed]

33. Kansky, A.A.; Didanovic, V.; Dovsak, T.; Brzak, B.L.; Pelivan, I.; Terlevic, D. Epidemiology of oral mucosal lesions in Slovenia. Radiol. Oncol. 2018, 52, 263-266. [CrossRef] [PubMed]

34. Kumar, S.; Narayanan, V.S.; Ananda, S.R.; Kavitha, A.P.; Krupashankar, R. Prevalence and risk indicators of oral mucosal lesions in adult population visiting primary health centers and community health centers in Kodagu district. J. Fam. Med. Prim. Care 2019, 8, 2337-2342. [CrossRef]

35. Sholapurkar, A.; Vengal, M.; Mathew, A.; Pai, K. The prevalence of oral mucosal lesions in patients visiting a dental school in Southern India. Indian J. Dent. Res. 2008, 19, 99. [CrossRef]

36. Bhatnagar, P.; Rai, S.; Bhatnagar, G.; Kaur, M.; Goel, S.; Prabhat, M. Prevalence study of oral mucosal lesions, mucosal variants, and treatment required for patients reporting to a dental school in North India: In accordance with WHO guidelines. J. Fam. Community Med. 2013, 20, 41-48. [CrossRef]

37. Cortés-Ramírez, D.A.; Rodríguez-Tojo, M.J.; Gainza-Cirauqui, M.L.; Martínez-Conde, R.; Aguirre-Urizar, J.M. Overexpression of cyclooxygenase-2 as a biomarker in different subtypes of the oral lichenoid disease. Oral Surg. Oral Med. Oral Pathol. Oral Radiol. Endodontology 2010, 110, 738-743. [CrossRef]

38. Kovač-Kavčič, M.; Skalerič, U. The prevalence of oral mucosal lesions in a population in Ljubljana, Slovenia. J. Oral Pathol. Med. 2000, 29, 331-335. [CrossRef]

39. Tortorici, S.; Corrao, S.; Natoli, G.; Difalco, P. Prevalence and distribution of oral mucosal non-malignant lesions in the western Sicilian population. Minerva Stomatol. 2016, 65, 191-206. Available online: http://www.ncbi.nlm.nih.gov/pubmed/27374359 (accessed on 27 November 2021).

40. Oivio, U.M.; Pesonen, P.; Ylipalosaari, M.; Kullaa, A.; Salo, T. Prevalence of oral mucosal normal variations and lesions in a middle-aged population: A Northern Finland Birth Cohort 1966 study. BMC Oral Health 2020, 20, 1-9. [CrossRef]

41. El Toum, S.; Cassia, A.; Bouchi, N.; Kassab, I. Prevalence and Distribution of Oral Mucosal Lesions by Sex and Age Categories: A Retrospective Study of Patients Attending Lebanese School of Dentistry. Int. J. Dent. 2018, 2018, 1-6. [CrossRef] [PubMed]

42. Babu, B.; Hallikeri, K. Reactive lesions of oral cavity: A retrospective study of 659 cases. J. Indian Soc. Periodontol. 2017, 21, 258-263. [CrossRef] [PubMed] 
43. Kumar Srivastava, V. To Study the Prevalence of Premalignancies in Teenagers having Betel, Gutkha, Khaini, Tobacco Chewing, Beedi and Ganja Smoking Habit and Their Association with Social Class and Education Status. Int. J. Clin. Pediatr. Dent. 2014, 7, 86-92. [CrossRef] [PubMed]

44. Pontes, C.C.; Chikte, U.; Kimmie-dhansay, F.; Erasmus, R.T.; Kengne, A.P.; Matsha, T.E. Prevalence of oral mucosal lesions and relation to serum cotinine levels-findings from a cross- sectional study in South Africa. Int. J. Environ. Res. Public Health 2020, 17, 65. [CrossRef]

45. Kusiak, A.; Maj, A.; Cichońska, D.; Kochańska, B.; Cydejko, A.; Świetlik, D. The Analysis of the Frequency of Leukoplakia in Reference of Tobacco Smoking among Northern Polish Population. Int. J. Environ. Res. Public Health 2020, 17, 6919. [CrossRef]

46. Rivera, C.; Droguett, D.; Arenas-Márquez, M.-J. Oral mucosal lesions in a Chilean elderly population: A retrospective study with a systematic review from thirteen countries. J. Clin. Exp. Dent. 2017, 9, e276-e283. [CrossRef] 